Computational Physics and Engineering Division

\title{
STRATEGIC ENVIRONMENTAL RESEARCH AND DEVELOPMENT PROJECT FY 1994: \\ ASSESSING NATIONAL REMOTE SENSING TECHNOLOGIES \\ FOR USE IN U.S. DEPARTMENT OF ENERGY \\ ENVIRONMENTAL RESTORATION ACTIVITIES \\ OAK RIDGE SOLID WASTE STORAGE AREA 4 CASE STUDY
}

\author{
Amy L. King \\ John L. Smyre \\ Thomas K. Evers
}

Date Published - February 1995

Sponsored by the

Strategic Environmental Research and Development Project (SERDP)

DOE Project \#2107-F129-A2

Prepared by the

Oak Ridge National Laboratory

Oak Ridge, Tennessee 37831-6274

managed by

MARTIN MARIETTA ENERGY SYSTEMS, INC.

for the

U.S. DEPARTMENT OF ENERGY

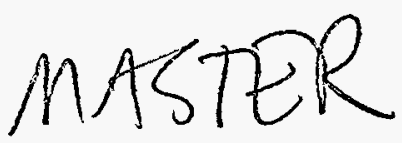

under contract DE-AC05-84OR21400

DISTPIBUTION OF THIS DOCUMENT IS UNLIMITED

DLC 


\section{DISCLAIMER}

This report was prepared as an account of work sponsored by an agency of the United States Government. Neither the United States Government nor any agency thereof, nor any of their employees, make any warranty, express or implied, or assumes any legal liability or responsibility for the accuracy, completeness, or usefulness of any information, apparatus, product, or process disclosed, or represents that its use would not infringe privately owned rights. Reference herein to any specific commercial product, process, or service by trade name, trademark, manufacturer, or otherwise does not necessarily constitute or imply its endorsement, recommendation, or favoring by the United States Government or any agency thereof. The views and opinions of authors expressed herein do not necessarily state or reflect those of the United States Government or any agency thereof. 


\section{DISCLAIMER}

Portions of this document may be illegible in electronic image products. Images are produced from the best available original document. 


\section{CONTENTS}

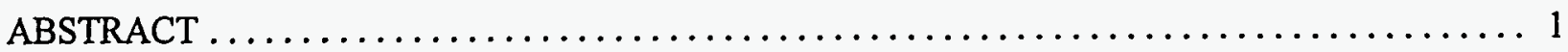

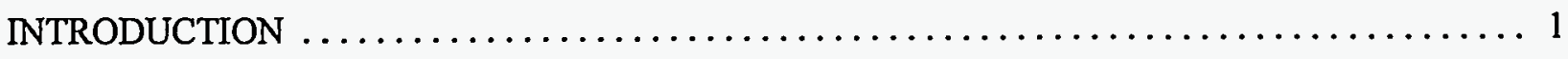

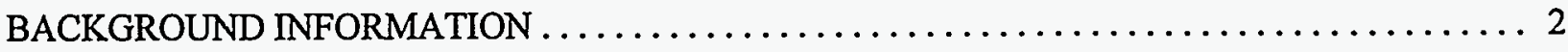

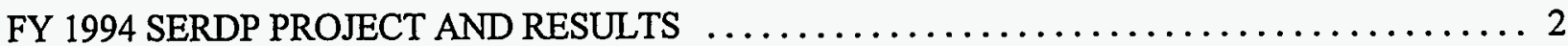

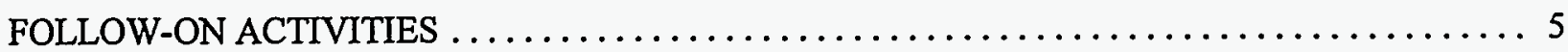

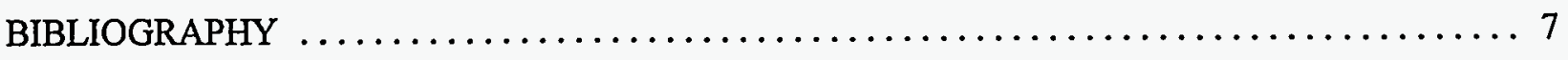

FURTHER INFORMATION AND CONTACTS $\ldots \ldots \ldots \ldots \ldots \ldots \ldots \ldots \ldots \ldots \ldots \ldots \ldots$ 


\title{
STRATEGIC ENVIRONMENTAL RESEARCH AND DEVELOPMENT PROJECT FY 1994: ASSESSING NATIONAL REMOTE SENSING TECHNOLOGIES FOR USE IN U.S. DEPARTMENT OF ENERGY ENVIRONMENTAL RESTORATION ACTIVITIES OAK RIDGE SOLID WASTE STORAGE AREA 4 CASE STUDY
}

\author{
Amy L. King \\ John L. Smyre \\ Thomas K. Evers
}

\begin{abstract}
During FY 1994, the Oak Ridge Environmental Restoration (ER) Remote Sensing Program teamed with members of the Oak Ridge National Security Program Office (NSPO), the Environmental Research Institute of Michigan (ERIM) under contract to the National Exploitation Laboratory (NEL), the Oak Ridge Waste Area Group 4 (WAG 4) ER Program, and the U. S. Department of Energy (DOE), Offices of Technology Development, Nonproliferation and National Security, and Environmental Restoration, to conduct a test and demonstration of the uses of national remote sensing technologies at DOE hazardous waste sites located in Oak Ridge, Tennessee. The objectives of the Oak Ridge study were to determine if national remote sensing technologies are useful in conducting prescreening, characterization, and/or monitoring activities to expedite the clean-up process at hazardous waste sites and to cut clean-up costs wherever possible. This project was sponsored by the Strategic Environmental Research and Development Project (SERDP).
\end{abstract}

\section{INTRODUCTION}

During FY 1994, the Oak Ridge Environmental Restoration (ER) Remote Sensing Program teamed with members of the Oak Ridge National Security Program Office (NSPO), the Environmental Research Institute of Michigan (ERIM) under contract to the National Exploitation Laboratory (NEL), the Oak Ridge Waste Area Group 4 (WAG 4) ER Program, and the U.S. Department of Energy (DOE), Offices of Technology Development, Nonproliferation and National Security, and Environmental Restoration, to conduct a test and demonstration of the uses of national remote sensing technologies at DOE hazardous waste sites located in Oak Ridge, Tennessee. Similar studies were conducted by the Savannah River Technology Center and the Los Alamos National Laboratory; only the studies conducted at the Oak Ridge sites will be discussed in this paper. The objectives of the Oak Ridge study were to determine if national remote sensing technologies are useful in conducting prescreening, characterization, and/or monitoring activities to expedite the clean-up process at hazardous waste sites and to cut clean-up costs wherever possible. 
The Oak Ridge study included data collection of several waste area groupings at the Oak Ridge National Laboratory (ORNL) and operable units at the Y-12 Plant. The site of primary focus was Solid Waste Storage Area 4 (SWSA 4) located within WAG 4 at ORNL. Other sites of interest included White Oak Lake (WAG 2) at ORNL and Bear Creek Operable Unit 1 at Y-12. WAG 4 is a shallow-waste-burial site located south of the main facility at ORNL. It consists of three separate areas: (1) SWSA 4, a shallowland burial ground containing radioactive and potentially hazardous wastes; (2) an experimental Pilot Pit Area, including a pilot-scale testing pit; and (3) sections of two abandoned underground pipelines formerly used for transporting liquid, low-level radioactive waste (Energy Systems 1994b). We focused our efforts on SWSA 4.

\section{BACKGROUND INFORMATION}

The SWSA 4 site was opened in February 1951 for routine burial of radioactively contaminated wastes and was closed to those wastes in 1963 (Bechtel 1988, Huff 1995). Explosive materials may have also been disposed of in SWSA 4 during this period. A variety of low- and high-activity wastes, including transuranic wastes were buried at the site. From 1959 until 1973 the site received nonradioactively contaminated construction debris (Duguid 1975). During the period 1955 through 1963 the site was also the Southern Regional Burial Ground for the Atomic Energy Commission (Davis and Shoun 1986). Approximately half of the wastes buried at SWSA 4 between 1951 and 1959 originated at ORNL; the remaining half were generated at more than 50 off-site locations, including the Oak Ridge Y-12 Plant, Argonne National Laboratory, Knolls Atomic Power Laboratory, Mound Laboratory, and the General Electric Company (Bechtel 1988). Disposal practices at SWSA 4 included burial in trenches and auger holes. Waste disposal records were destroyed in a fire in 1957 (Energy Systems 1994a).

As presented in the Preliminary Assessment Report (Energy Systems, 1994a), several investigations have been performed at WAG 4 in addition to the routine monitoring, environmental monitoring, and sampling program activities implemented for the Oak Ridge Reservation. These investigations have focused on the characterization of soils, waste trenches, surface water and sediments, and groundwater. Investigations have consisted of radiation surveys, media chemical analyses, and flow measurements (Energy Systems 1994b). As part of the Oak Ridge Environmental Restoration Remote Sensing Program, aerial surveillance of the site has included airborne radiological monitoring, airborne and ground-based geophysics surveillance (electromagnetic and magnetic data collection), multispectral scanner imagery acquisition and analyses, natural color and color infrared photography acquisition, and predawn thermal data acquisition and analyses.

\section{FY 1994 SERDP PROJECT AND RESULTS}

The main focus of the FY 1994 SERDP project at SWSA 4 was the identification of buried trench locations. As discussed previously, all historic records of this site were burned in a fire in 1957. A trench map displaying the approximate areas and general orientation of the trenches is available for the site (Figure 1). The map was developed by free-hand copying of a trench map that was maintained by a site foreman when the trenches were dug at SWSA 4. The map was copied before the original map was destroyed in the fire. Recollections by retirees were also incorporated into the map. Our goal in this focus area was to provide a better understanding of the trench locations at SWSA 4. The project delivered an unclassified derived product map of trench signatures for the SWSA 4 site (Figure 2). The map was given to the WAG 4 ER groundwater specialist and the site's investigation team to enhance their knowledge of the trench locations. 


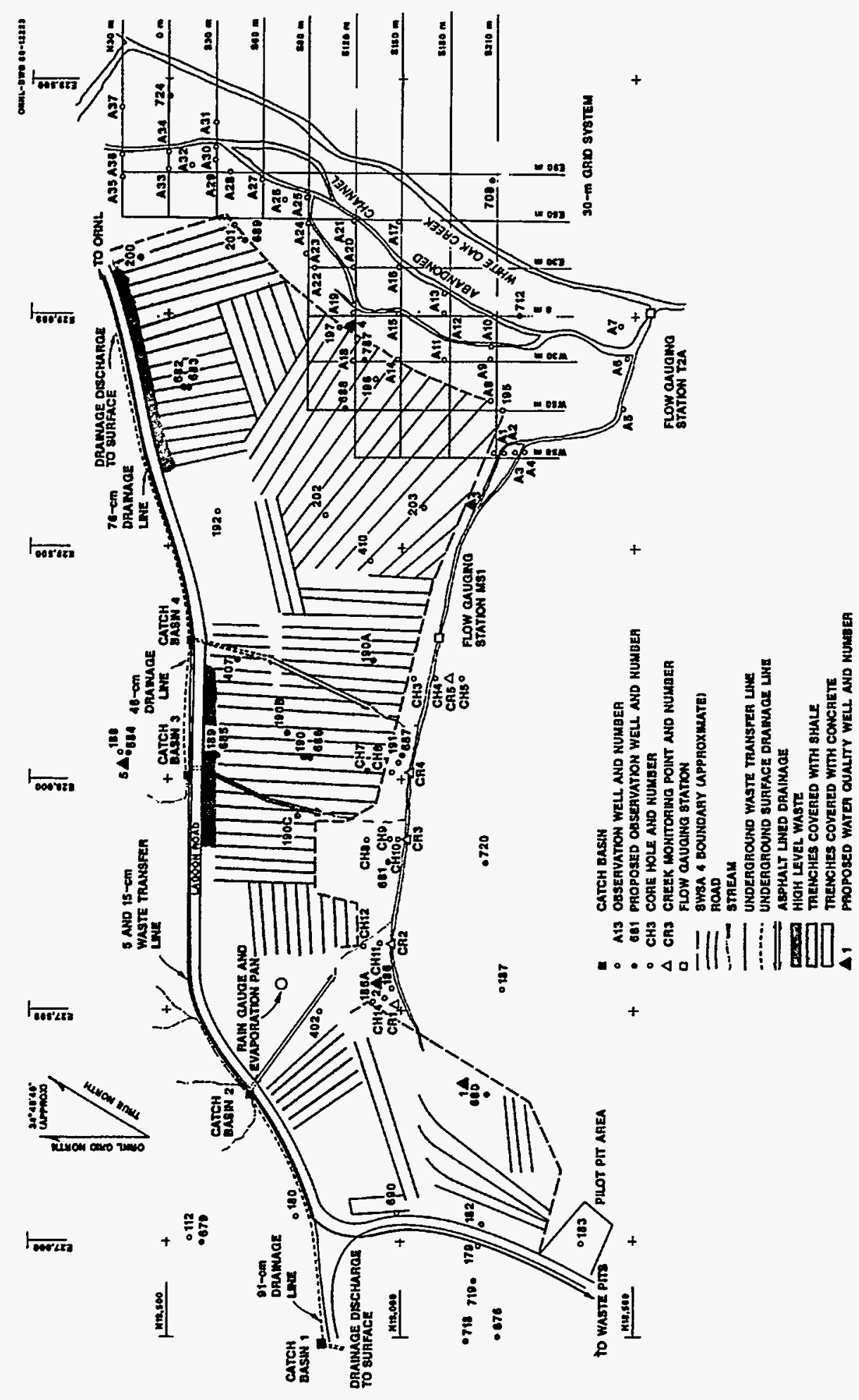

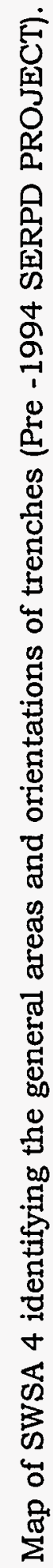

ㄱ. 


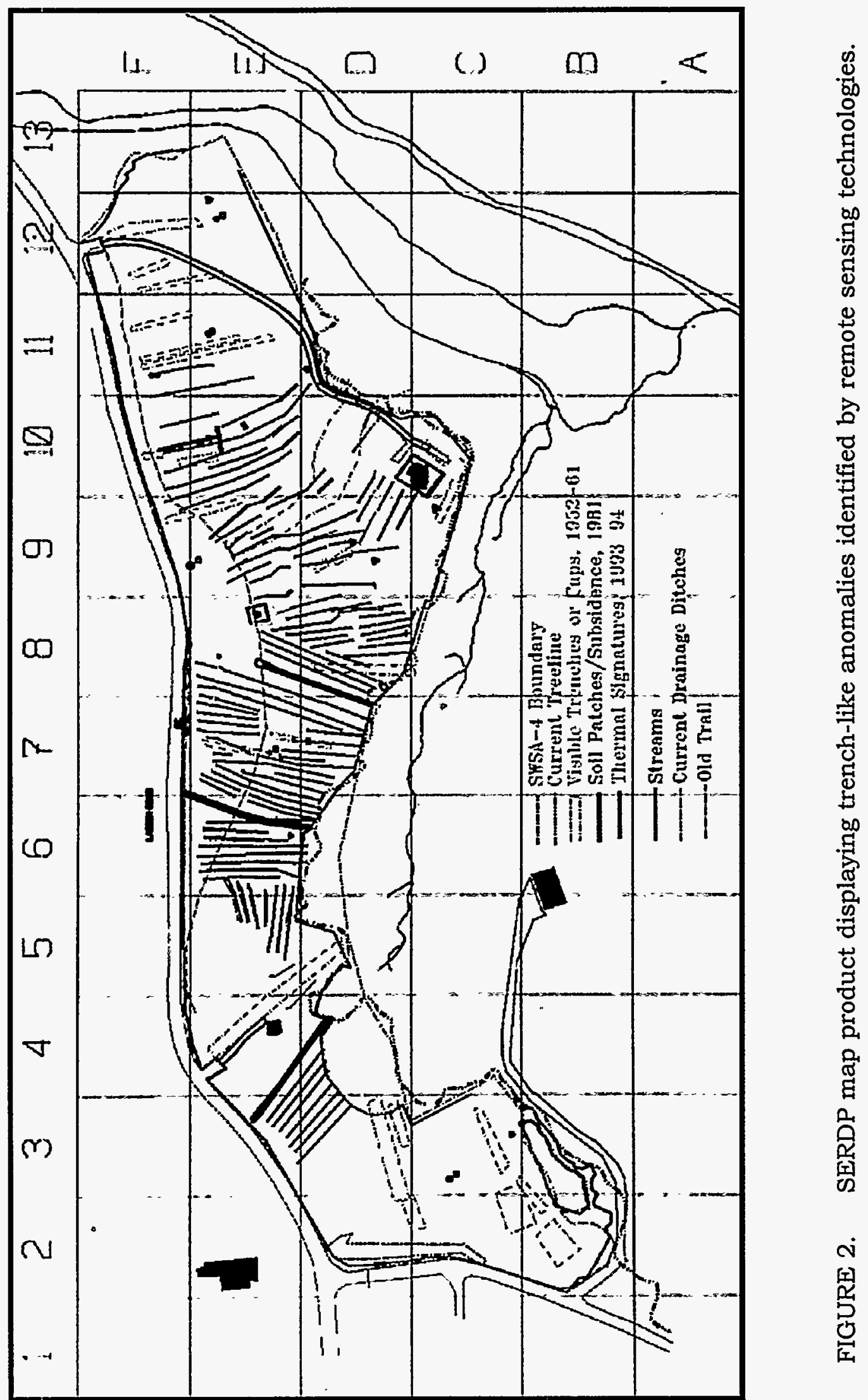


The Oak Ridge team (ER Remote Sensing, National Security Program Office, WAG 4 ER team) coordinated the Oak Ridge project activities, conducted ground truth activities, provided the ERIM scientists with the environmental investigation data and aerial surveillance data, and acted as information consultants to the ERIM scientists. ERIM scientists conducted exploitation and analyses of national remote sensing data for the Oak Ridge sites, as well as identifying and acquiring historical imagery for the sites. DOE team members acted as liaisons in acquiring national remote sensing data for Oak Ridge sites, provided oversight of the project, attended SERDP managers meetings, and acted as liaisons for funding of the project. For a discussion of the data acquisition, fusion, and analyses conducted during this project, note the SERDP Waste Site Study, Phase II: Final Report (SERDP 1994).

\section{FOLLOW-ON ACTIVITIES}

Several follow-on activities from the FY 1994 SERDP project are planned. During FY 1995, the Oak Ridge Team, along with ERIM and DOE, will be involved with the Government Applications Task Force (GATF). The GATF project is being conducted in cooperation with scientists at Los Alamos National Laboratory and the Savannah River Technical Center to verify the studies conducted at each of the sites during FY 1994 under SERDP. The teams are currently planning ground truth activities to test soil moisture, temperature, emissivity, and albedo. These ground truth activities, in conjunction with additional national remote sensing data analyses and data fusion, will provide a more scientific approach to verifying the applications of National Remote Sensing Technologies to Environmental Restoration problems. WAG 4 ER investigations to verify the locations of the derived product signatures are currently under way. As discussed in the WAG 4 Sampling and Analysis Plan (Energy Systems 1994b),

...the new remote sensing data have made it possible to resolve some of the remaining issues about the WAG 4 trench areas. Such resolution would enhance the potential for developing and implementing more economical and effective alternatives for interim remedial measures. The basic issue to be addressed is to determine the minimum area of the source that can be controlled to successfully reduce (to $\geq 90 \%$ ) the release of ${ }^{\infty} \mathrm{Sr}$ from WAG 4 to White Oak Creek. This requires a better understanding of the "Sr "source area" sizes, locations, dynamics,

The Oak Ridge SERDP study of SWSA 4 has indicated that the identification of residual trench and pit signatures is possible from the use of national remote sensing. The applications identified during the FY 1994 SERDP project are being verified by a portion of the FY 1995 GATF project and by the WAG 4 ER team. The widespread use of technologies identified during this collaborative project to better screen and characterize environmental restoration sites would result in a more efficient use of government funds and an expedited clean-up process. The ability to locate trench and pit signatures at sites that are not well documented could save years of investigation to find the trench and pit areas and millions of clean-up dollars, by focusing remedial alternative efforts on the areas containing buried wastes where possible. The Oak Ridge team is currently discussing the project results with other ER WAG and Operable Unit investigation teams to apply the national remote sensing capabilities to other Oak Ridge sites. Similar activities are being conducted at Los Alamos National Laboratory and the Savannah River Technology Center. We would also like to apply the techniques to Department of Defense sites, where these capabilities could save additional governmental dollars. 


\section{BIBLIOGRAPHY}

Bechtel (Bechtel National, Inc.) May 1988. Remedial Investigation Plan for ORNL Waste Area Grouping 4,Oak Ridge National Laboratory Remedial Investigation/ Feasibility Study, ORNL/RAP/Sub8/99053/11, Martin Marietta Energy Systems, Inc. Oak Ridge Natl. Lab., Oak Ridge, Tenn.

Davis, E. C. and R. R. Shoun. September 1986. Environmental Data Package for ORNL Solid Waste Storage Area Four, the Adjacent Intermediate-level Liquid Waste Transfer Line, and the Liquid Waste Pilot Pit Area, ORNL/TM-10155, Martin Marietta Energy Systems, Inc., Oak Ridge Natl. Lab., Oak Ridge, Tenn.

Duguid, J. O. July 1975. Status Report on Radioactivity Movement from Burial Grounds in Melton and Bethel Valleys. ORNL-5017, Union Carbide Corp. Nuclear Div., Oak Ridge Natl. Lab., Oak Ridge, Tenn.

Huff, Dale. Personal communication between Dr. Dale D. Huff and Amy L. King, January 14, 1995. Oak Ridge Natl. Lab., Oak Ridge, Tenn.

Martin Marietta Energy Systems, Inc., October 1994a. Preliminary Assessment Report for Waste Area Grouping 4 at Oak Ridge National Laboratory, Oak Ridge, Tennessee, ORNL/ER-271, Martin Marietta Energy Systems, Inc., Oak Ridge Natl. Lab., Oak Ridge, Tenn.

Martin Marietta Energy Systems, Inc., December 1994b, Waste Area Grouping 4 Site Investigation Sampling and Analysis Plan, Oak Ridge National Laboratory, Oak Ridge, Tennessee. DOE/OR/011337\&D1, Martin Marietta Energy Systems, Inc., Oak Ridge Natl. Lab., Oak Ridge, Tenn.

SERDP (Strategic Environmental Research and Development Program) December 1994. SERDP Waste Site Study, Phase II: Final Report. Prepared by the National Exploitation Laboratory, under contract 94-K247500-000. December. (SECRET)

\section{FURTHER INFORMATION AND CONTACTS}

The WAG 4 ER follow-on activities scheduled to begin in January 1995 are described in detail in the following report:

Martin Marietta Energy Systems, Inc., December 1994b. Waste Area Grouping 4 Site Investigation Sampling and Analysis Plan, Oak Ridge National Laboratory, Oak Ridge, Tennessee. DOE/OR/011337\&D1. Martin Marietta Energy Systems, Inc., Oak Ridge Natl. Lab., Oak Ridge, Tenn.

The detailed discussion of the entire FY 1994 SERDP project is discussed in the following report:

SERDP (Strategic Environmental Research and Development Project) December 1994. SERDP Waste Site Study, Phase II: Final Report. National Exploitation Laboratory, under contract 94-K247500-000. December. (SECRET) 
The authors of this report can be contacted by telephone, mail, or internet at the following addresses:

Ms. Amy Delf King
615-576-1509
P.0. Box 2008
Oak Ridge National Laboratory
Computational Physics and Engineering
Division
4500-N, MS 6274
Oak Ridge, Tennessee 37831-6274
internet: kingal@ornl.gov

\section{Ms. Amy Delf King}

Oak Ridge National Laboratory

Division

Oak Ridge, Tennessee 37831-6274

internet: kingal@ornl.gov
Mr. John L. Smyre

615-574-2969

P.O. Box 2008

Oak Ridge National Laboratory

Computational Physics and Engineering

Division

4500-N, MS 6274

Oak Ridge, Tennessee 37831-6274

internet: smyrejl@ornl.gov
Mr. Thomas K. Evers

615-574-8704

P.O. Box 2008

Oak Ridge National Laboratory

Computational Physics and Engineering

Division

4500-N, MS 6274

Oak Ridge, Tennessee 37831-6274

internet: everstk@ornl.gov 


\section{INTERNAL DISTRIBUTION}

1. D. T. Bell

2. H. L. Boston

3. R. B. Cook

4. M. F. DeLozier

5. R. C. Durfee

6. J. E. Dobson

7-11. T. K. Evers

12. J. T. Grumski

13. M. E. Hodgson

14. R. K. Holmes

15. D. D. Huff

16. B. L. Kimmel

17-21. A. L. King

22. L. A. Knapp
23. M. A. Kuliasha

24. J. R. Lyons

25. D. K. Parker

26. D. H. Pike

27-29. C. H. Shappert

29-33. J. L. Smyre

34. R. K. White

35. T. F. Zondlo

36. Central Research Library

37. ORNL Y-12 Technical Library Document Reference Section

38. Laboratory Records Department

39. Laboratory Records Department, RC

40. ORNL Patent Office

\section{EXTERNAL DISTRIBUTION}

Environmental Research Institute of Michigan, 1101 Wilson Blvd., Suite 1100, Arlington, VA 22209-2248 41. J. M. Irvine

Environmental Research Institute of Michigan, P.O. Box 134001, Ann Arbor, MI 48113-4001

42. J. B. Odenweller

43. G. Stahl

U.S. Department of Energy, Oak Ridge Operations, P.O. Box 2001, Oak Ridge, TN 37831

44. D. M. Carden

45. S. P. Riddle

46. R. C. Sleeman

U.S. Department of Energy, 1000 Independence Avenue, SW, Washington, DC 20585

47. W. R. Bell, Office of Nonproliferation and National Security

48. G. R. Maxwell, Office of Nonproliferation and National Security

49. C. L. Nalezny, Office of Technology Demonstration

50. Office of Deputy Assistant Manager for Energy Research and Development, Department of Energy, Oak Ridge Operations, P.O. Box 2008, Oak Ridge, TN, 37831-6269

51-52. Office of Scientific and Technical Information, U.S. Department of Energy, P.O. Box 62, Oak Ridge, TN 37831 